\title{
Surface ozone monitoring and background characteristics at Zhongshan Station over Antarctica
}

\author{
WANG YuTing ${ }^{1}$, BIAN LinGen ${ }^{1 *}$, MA YongFeng ${ }^{1,2}$, TANG Jie $^{1}$, ZHANG DongQi $^{1}$ \& \\ ZHENG XiangDong ${ }^{1}$ \\ ${ }^{1}$ State Laboratory of Severe Weather, Chinese Academy of Meteorological Sciences, Beijing 100081, China; \\ ${ }^{2}$ Graduate University of Chinese Academy of Sciences, Beijing 100049, China
}

Received November 4, 2010; accepted January 5, 2011

\begin{abstract}
Seasonal variation in surface ozone and the relationship between the background ozone concentration and wind were evaluated at Zhongshan Station, Antarctica using 2008 data. The wind frequency from the station area was only $2 \%$, while the prevailing wind frequency was much larger $(79.2 \%)$. This indicates that the surface ozone observations were not affected by the human activities at the station, and therefore could be counted as background concentrations of surface ozone along Antarctic coast. The concentration of surface ozone shows a distinct annual variation with the yearly mean of $25.0 \mathrm{nmol} \mathrm{mol}^{-1}$ and the maximum in winter, the minimum in summer. The surface ozone concentration had a strong negative correlation with ultraviolet radiation, and the mean values during polar night were one to two times higher than those in summer. These results imply that photochemical destruction of ozone dominates over Antarctica. The ozone depletion events at Zhongshan Station were obviously related to lower temperatures and higher $\mathrm{BrO}$ concentrations. Backward trajectory analysis reveals that the ozone depletion events are predominately caused by the high $\mathrm{BrO}$ concentrations.
\end{abstract}

Antarctica, Zhongshan Station, surface ozone, background characteristics, ODE

Citation: Wang Y T, Bian L G, Ma Y F, et al. Surface ozone monitoring and background characteristics at Zhongshan Station over Antarctica. Chinese Sci Bull, 2011, 56: 1011-1019, doi: 10.1007/s11434-011-4406-2

Ozone is a key component of the atmosphere, and although it is present at a very low concentration, it seriously influences the global climate system and could affect the existence of life on earth [1]. In the atmosphere $90 \%$ of the ozone is distributed in the stratosphere while only $10 \%$ in the troposphere [2]. The Intergovernmental Panel on Climate Change (IPCC) fourth assessment report [3] presented estimated values of radiative forcing from stratospheric and tropospheric ozone are $-0.05 \pm 0.10 \mathrm{~W} \mathrm{~m}^{-2}$ and $0.35 \pm 0.15 \mathrm{~W} \mathrm{~m}^{-2}$. respectively. Ozone in the lower atmosphere is related to the generation of hydroxyl radical $(\mathrm{OH})$ and oxynitride, and ozone itself is an important oxidant, which can remove many natural and synthetic atmospheric pollutants [4]. Ozone strongly absorbs solar radiation and is thus an effect-

*Corresponding author (email: blg@cams.cma.gov.cn) tive greenhouse gas [5-7]. Increasing ozone concentration will also cause serious atmospheric pollution and is extremely harmful to human beings, animals and plants as well as the ecological environment. Therefore, attention has focused on the study and monitoring of tropospheric ozone.

The tropospheric ozone concentration has been increasing year by year, and has at least doubled since the Industrial Revolution. To obtain the background concentration and variation tendency of surface ozone is of great importance for assessing the influence of human activities and providing background information for the government making emission-reduction policies [8]. Estimates of sea level, natural atmospheric ozone levels prior to anthropogenic influences are in the range of 10-15 $\mathrm{nmol} \mathrm{mol}^{-1}$, however, in recent years the concentrations observed by many background stations are in the $30-60 \mathrm{nmol} \mathrm{mol}^{-1}$ 
range. The increase, to a great extent, is attributed to human activities, which result in increased emission of ozone photochemical precursors [7].

The Antarctic area is regarded as the background of global atmosphere, because it is minimally affected or polluted by human activities. The sources of the tropospheric ozone in this area are limited and its concentration is mainly determined by photochemical reaction production, longdistance transportation and the downward transportation of stratospheric ozone [7]. Hence, surface ozone trends over Antarctica are indicative for the variation of global surface ozone concentration. Surface ozone observation over Antarctica started in the 1950s, till now, however, the Global Atmosphere Watch (GAW) program of the World Meteorological Organization (WMO) only has two global stations and several regional stations carrying out long-term surface ozone observations in the Antarctic area (http:// www.wmo.int/pages/prog/arep/gaw/gaw_home_en.html). Compared with other areas, observational data of surface ozone in Antarctic is still rare.

Surface ozone concentrations over Antarctica display an obvious seasonal variation with high concentrations in winter and low in summer [9]. The amplitude of the seasonal variation is about $50 \%$ of the annual mean concentration [10]. Oltmans [11] noted in the 1980s that episodes of low surface ozone concentrations were measured at Barrow, Alaska in late winter and early spring. These episodes were called ozone depletion events (ODE). ODE were also observed in the Antarctic at the end of the 1990s [12]. It is found that strong ODE coincided with high levels of filterable bromine, which suggested that halogens were involved in the ozone depletion process $[13,14]$. The main source of reactive bromine species $(\mathrm{Br}$ and $\mathrm{BrO})$ is bromide from sea salt, and it is released through photochemical reactions known as bromine explosion. However, it remains unclear how bromide in sea salts is transformed into gas phase. Under the condition of low temperature, $\mathrm{BrO}$ can be released in the process of frost flowers formation on the young sea ice surface [15]. Recent satellite observations have shown that
BrO clouds are mostly present over the young sea ice [16].

Chinese studies on polar ozone mainly focus on Antarctic ozone holes, ozone column change and ozone vertical profiles. In 1993 the ninth China Antarctic expedition team started the observation of total ozone column and ultraviolet radiation (UVB) with an ozone spectrograph (Brewer) at Zhongshan Station. Zhou et al. [17] and Zheng et al. [18,19] pointed out that total ozone column changed greatly when ozone holes were present in spring at Zhongshan Station, which might be related to the fact that Zhongshan Station is located at the edge of Antarctic spring ozone holes and would be affected by the polar vortex and rapid changes of ozone holes. It was also related to the strengthening of UVB. Guo et al. [20] suggested that ozone reduction mainly took place on the lower level of stratosphere. Based on the surface ozone data collected on the China First Arctic Expedition and the 16th Antarctic Expedition (1999-2000), Lu et al. [21] found the surface ozone concentration varied with latitude and had different diurnal cycle at different latitude. Xie et al. [22] analyzed the relationship of ozone in the Arctic troposphere with mercury losses in atmosphere and sea ice evolution.

With the support of the Fourth International Polar Year (2008/2009) China Action Plan, the 24th Antarctic scientific expedition team built an atmosphere monitoring station on Antarctica. This allowed continuous atmosphere background monitoring for the first time at Zhongshan Station. In this paper, surface ozone and meteorological observations at Zhongshan Station in 2008 were analyzed along with other relevant data to evaluate the background surface ozone concentration and its seasonal variation.

\section{Observation environments and data acquisition}

Figure 1 shows the location and geography of the atmosphere monitoring site at Zhongshan Station and the landscape in summer. The monitoring site is situated in a flat area $\left(69^{\circ} 22^{\prime} 12^{\prime \prime} \mathrm{S}, 76^{\circ} 21^{\prime} 49^{\prime \prime} \mathrm{E}\right.$, altitude $\left.18.5 \mathrm{~m}\right)$ west of the
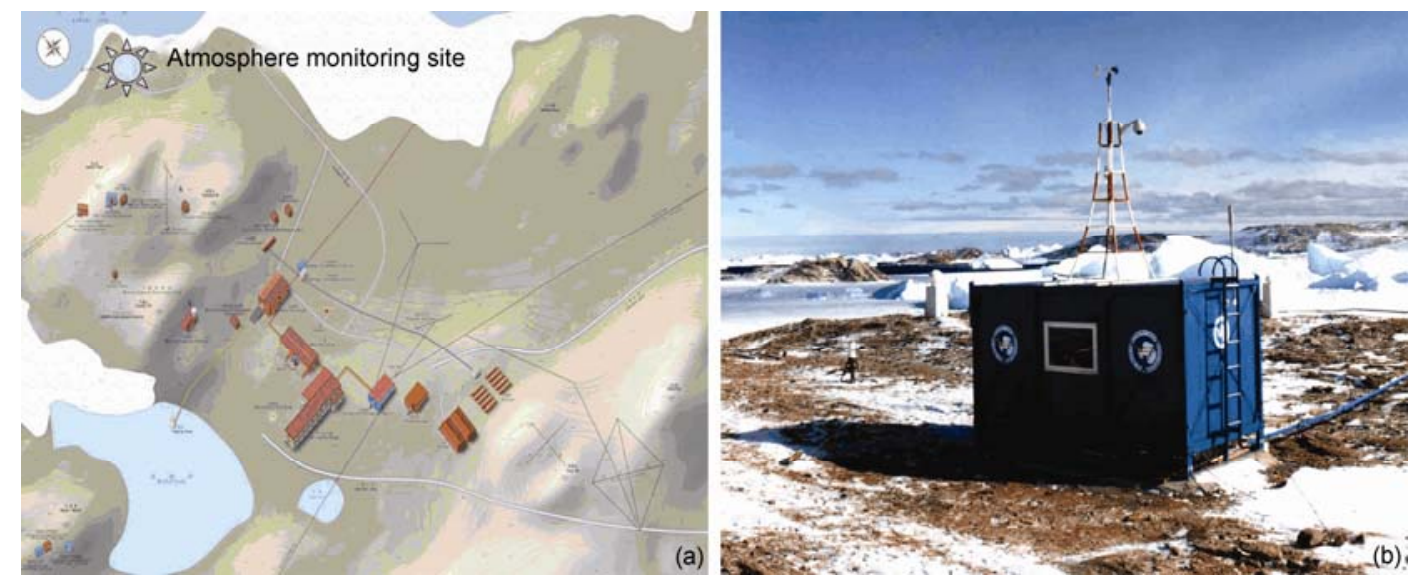

Figure 1 The location of atmosphere monitoring site at Zhongshan Station (a) and the landscape in summer (b). 
Swan Mountain ridge, which is in the northwest of Zhongshan Station. It is surrounded by Neila Fiord in the north and west, Double Peak Mountain in the northeast and Xiaoxitian in the southwest. To the southeast are Front Hillside, Scenic Hill and Meteorology Hill, in which the most observation facilities are concentrated. The prevailing wind here is easterly.

Surface ozone concentrations were observed by standard instruments, including a UV absorption surface ozone analyzer (EC9810A) and a UV absorption ozone calibrator (EC9811). These instruments meet the requirements of the atmosphere background-monitoring standard of the WMO. The observation system has its own information storage with acquisition frequency of 3 minutes and it is available for real-time downloading. Furthermore, to prevent data losses, a CR1000 data logger is used to record the data output in real-time by EC9810A. Every three months the ozone analyzer is calibrated using the Ozone calibrator. For each calibration, five standard ozone marker gases are used and the measured data of EC9811 and EC9810A are recorded. In 2008 five calibrations were made and the related coefficients $(r)$ were all greater than 0.9995 . These met the quality requirement of observation data calibration. In addition, we also used the surface ozone data of other Antarctic stations in 2008 from the World Data Centre for Greenhouse Gases (WCDGG) under the GAW program and the distribution of atmospheric $\mathrm{BrO}$ vertical column [23,24] monitored by SCIAMACHY satellite of the Institute of Environmental Physics, University of Bremen, Germany (http://www.iup. unibremen.de/doas/bro_from_scia.htm).

Surface ozone concentration data collected every $3 \mathrm{~min}$ from January to December of 2008 were processed to obtain the hourly mean data. Variance test was used to remove the abnormal value of the data on the basis of formula $\left|x_{i}-\bar{x}\right|>3 \sigma$, where $x_{i}$ is measured value, $\bar{x}$ is time series mean and $\sigma$ is the standard deviation. After processing, $95.6 \%$ of the hourly mean data was retained.

\section{Results and discussion}

\subsection{Impact of local wind on observed surface ozone concentration}

Local surface wind is an important factor that causes fluctuations in observation [25,26]. To study the background features of surface ozone and its sources and sinks, it is important to extract observational data that is not directly affected by regional factors. In consideration of the prevailing wind direction, ozone monitoring is conducted in the northwest of Zhongshan Station. The most probable pollution sources in this area are the power generation building and the garbage incinerator, which are located to the southeast of the monitoring building at a distance of about $400 \mathrm{~m}$. The monitoring building is separated from the power generation building and the garbage incinerator by Front Hillside, Scenic Hill and Meteorology Hill. Observational data would only be affected by these sources under a southeast wind (SE).

Figure 2 shows a wind rose of 16 directions and the corresponding mean surface ozone concentration for each wind direction during 2008. The prevailing winds at Zhongshan Station in 2008 were east (E) and easterly winds $\left(45^{\circ}-\right.$ $135^{\circ}$ ), and occurred $79.2 \%$ of the time. This indicated the airflow reaching the atmospheric monitoring station was mainly from easterly coastal areas and sea areas in the northeast. The average concentration of surface ozone under $\mathrm{E}$ was the highest of all the wind directions at $26.8 \mathrm{nmol} \mathrm{mol}^{-1}$. This was followed by the concentrations under easterly winds, westerly winds and southwest wind (SW). Under north $(\mathrm{N})$ or northerly winds, the average concentration of surface ozone was the lowest of $16 \mathrm{nmol} \mathrm{mol}^{-1}$, at least 5 nmol mol ${ }^{-1}$ lower than that under other wind directions. This might result from a low ozone content in the air mass from the sea. When there appeared a SE wind $\left(135^{\circ}\right)$, the surface ozone concentration did not increase and the average concentration was $22.8 \mathrm{nmol} \mathrm{mol}^{-1}$. This may be because the SE wind occurred less frequently (only $2 \%$ of the time) than other winds, and consequently had no significant influence on the observation. To further study the impact of wind directions on surface ozone concentration in different seasons, the wind direction and wind speed data were analyzed for each month (Figure 3). At Zhongshan Station, the prevailing wind directions for January, February, November and December (austral summer) in 2008 was northeast wind (NE), while the prevailing wind direction for other months was east-northeast wind (ENE). From Figure 3, it can be concluded that the wind direction did not evidently

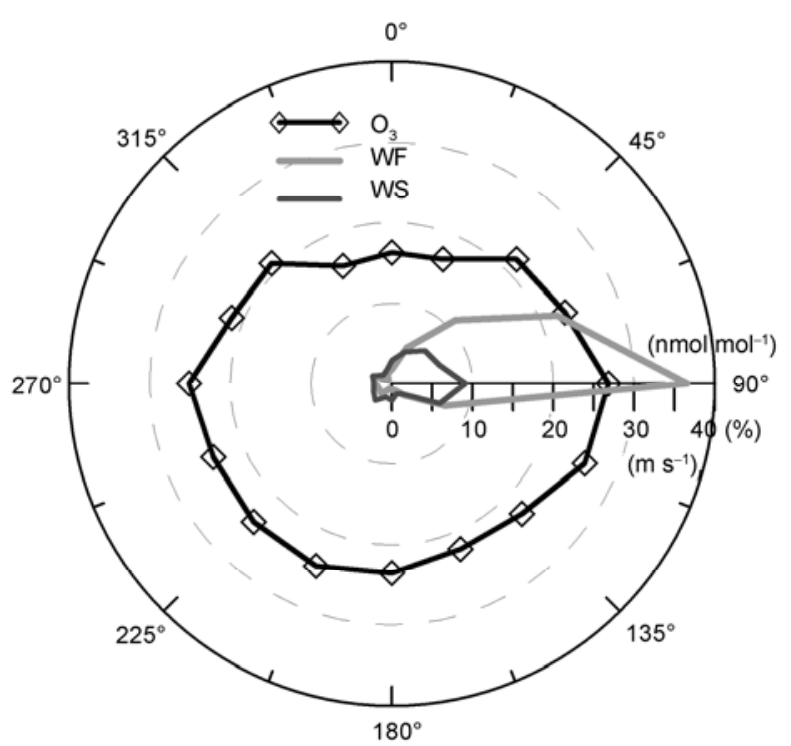

Figure 2 Wind direction rose and the corresponding wind speed (WS) and surface ozone $\left(\mathrm{O}_{3}\right)$ concentration for 2008 . 
influence the surface ozone concentration. The only times the surface ozone concentration increased compared to other times was under northwest wind (NW) or south-southeast wind (SSE), but the occurrence of these winds was very small $(<1 \%)$. This might result from the limited samples. To exclude its influence on the background concentration, we eliminate these data from our analysis. The monthly wind rose shows that when the wind was $\mathrm{N}$, the surface ozone concentration did not decrease significantly, which was different to the distribution for the whole year. This might be caused by high frequency of northerly winds in the summer months, in which the surface ozone concentration is low.
To analyze the impact of wind speed on ozone concentration, the wind speed data for all of 2008 were divided into seven groups as follows: $<0.5,0.5-3,3-6,6-10,10-15$, $15-20$ and $>20 \mathrm{~m} \mathrm{~s}^{-1}$. Figure 4 shows the average concentration of surface ozone under the corresponding wind speed. The wind speeds at Zhongshan Station were mainly ( $93.7 \%$ of the data) in the range of $0.5-15 \mathrm{~m} \mathrm{~s}^{-1}$. From Figure 4 , it can be seen that the surface ozone concentration did not change much under different wind speed conditions, and the range was less than $5 \mathrm{nmol} \mathrm{mol}{ }^{-1}$. Figure 5 shows the distribution of surface ozone concentration under the different wind speed ranges for each month. The surface ozone
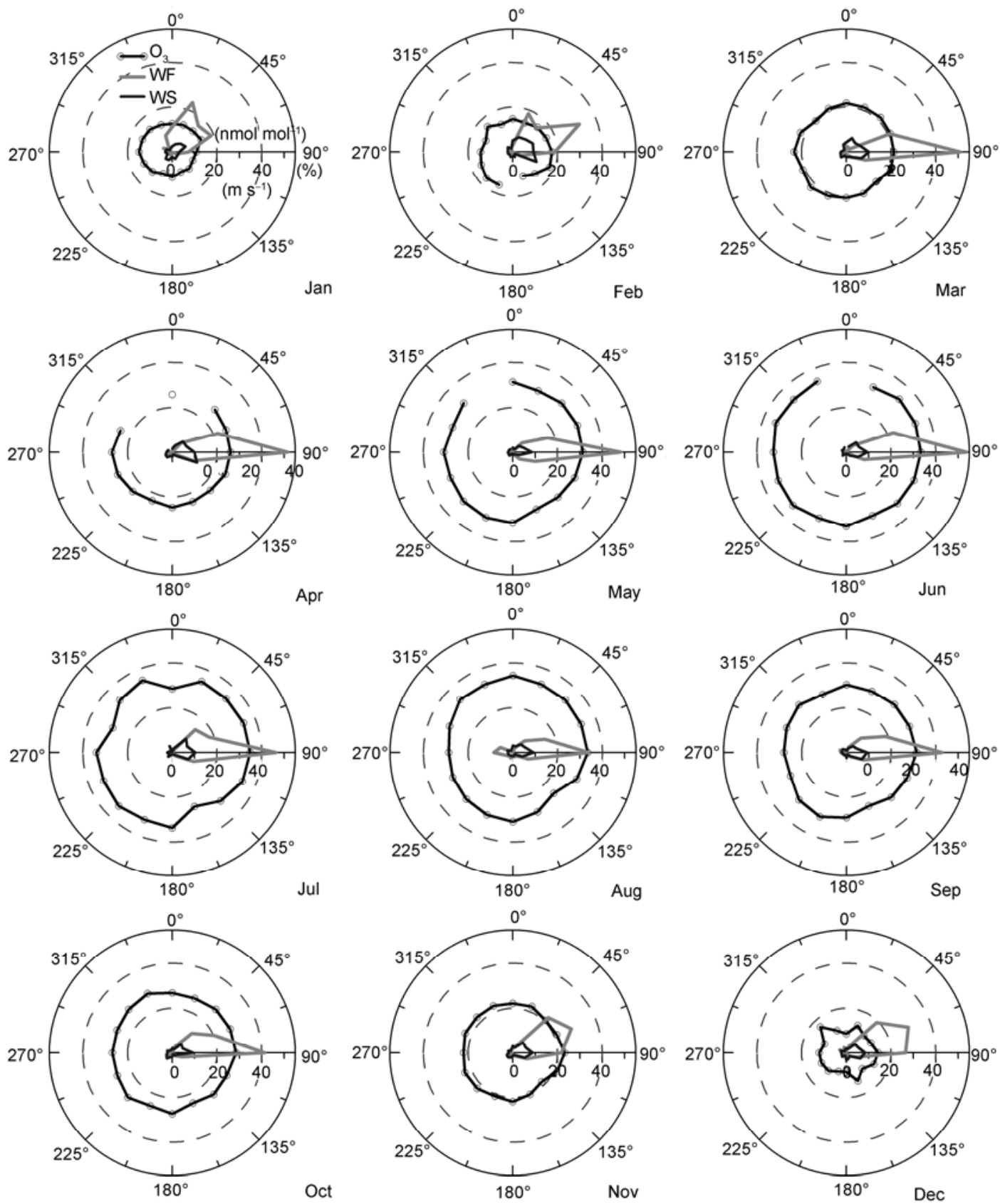

Figure 3 Wind direction rose and the corresponding wind speed (WS) and surface ozone $\left(\mathrm{O}_{3}\right)$ concentration for each month of 2008. 


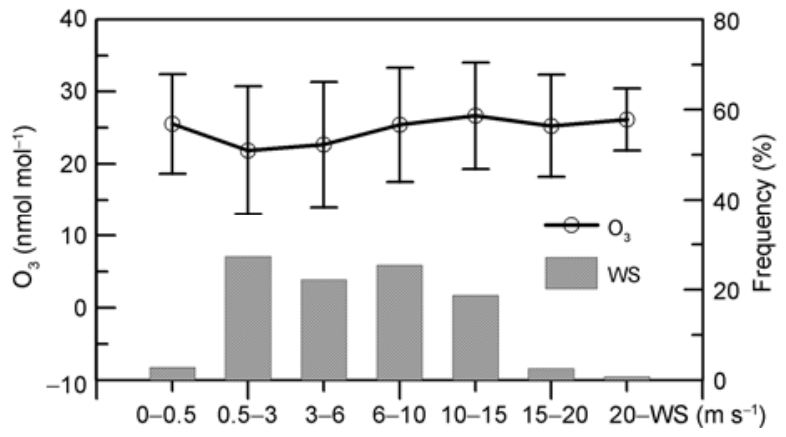

Figure 4 The frequency of different wind speed levels and the corresponding surface ozone $\left(\mathrm{O}_{3}\right)$ concentration for 2008 .

concentration of each month did not change much with the changes in wind speed. However, in the austral summer (November, December, January and February), the surface ozone concentration rose to a certain degree when the wind speed increased, which shows that in summer the transport had an impact on surface ozone concentration. To exclude this impact, we also remove these data (about $1 \%$ of the data) from the analysis.

After the processing discussed above, $94.7 \%$ of hourly
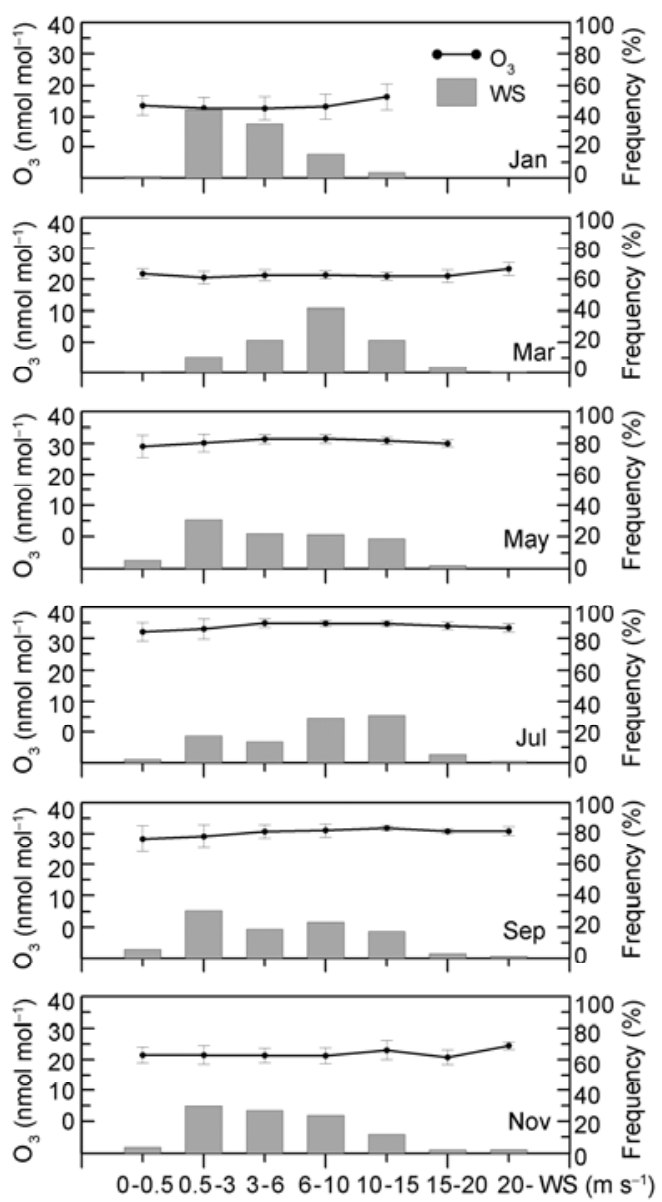

mean data was retained. This indicates that regional pollution around Zhongshan Station has a very small impact on surface ozone concentration. Therefore, the processed surface ozone data can be used to represent the background ozone concentration of Zhongshan Station.

\subsection{Seasonal variation of surface ozone}

Figure 6 shows the time series of the hourly mean concentration of surface ozone at Zhongshan Station in 2008. The surface ozone concentration had a significant annual variation with the high values in winter and low in summer. The maximum appeared in July with monthly mean concentration of $34.4 \mathrm{nmol} \mathrm{mol}^{-1}$ while the minimum appeared in December with monthly mean concentration of $12.3 \mathrm{nmol} \mathrm{mol}^{-1}$. This is similar to the seasonal variation of surface ozone at other Antarctic stations [7]. The concentration of ozone precursors like nitrogen oxides in Antarctica is very low all year long. However, in the austral summer solar radiation is so strong that the ozone destruction by ultraviolet radiation is dominant over its photochemical production, and consequently the surface ozone concentration is low in summer in Antarctica [27]. By contrast, the surface ozone concentration
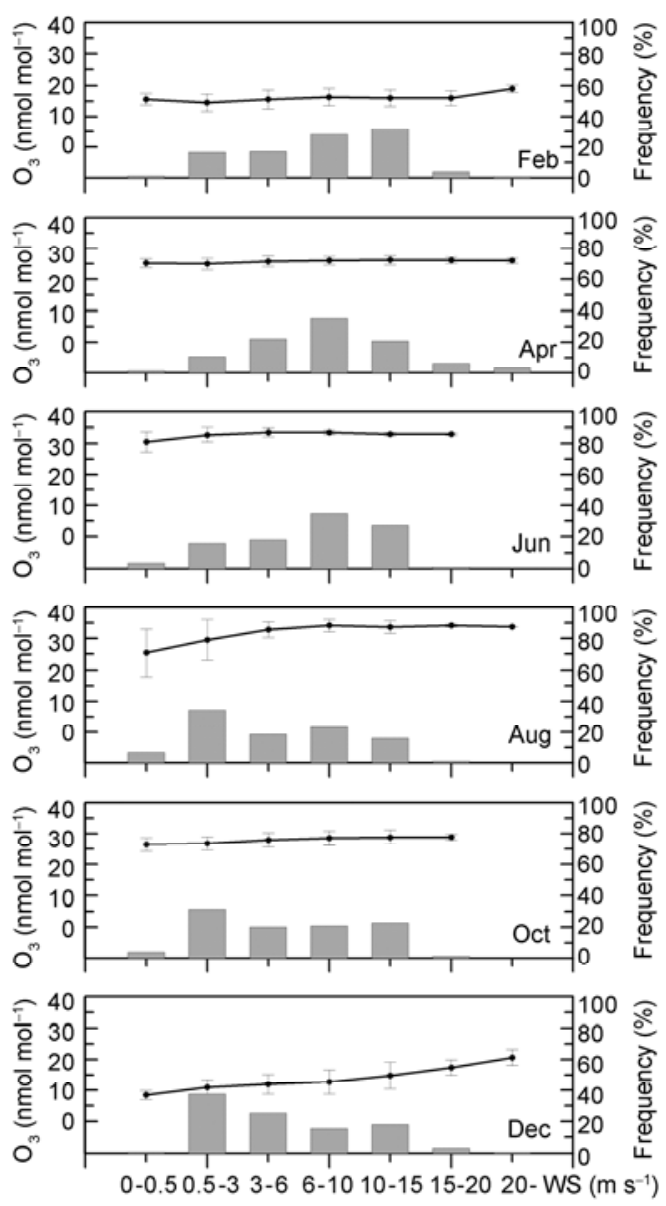

Figure 5 The frequency of different wind speed levels and the corresponding surface ozone $\left(\mathrm{O}_{3}\right)$ concentration for each month of 2008 . 


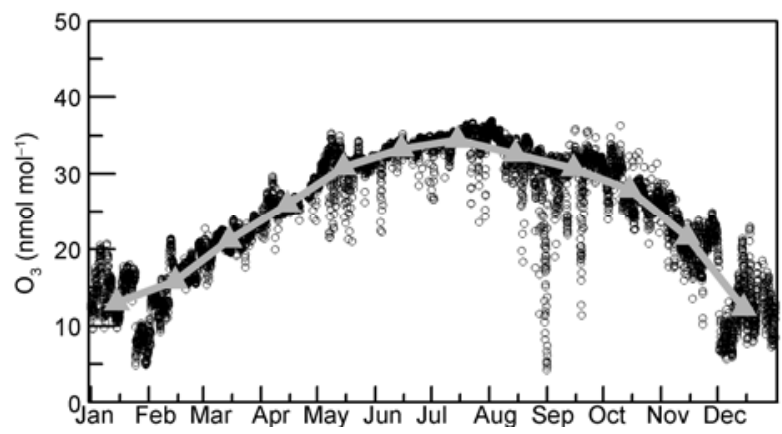

Figure 6 Hourly mean surface ozone $\left(\mathrm{O}_{3}\right)$ concentrations in 2008. The solid line is the monthly mean.

is high in winter because there is no solar radiation during the polar night period in austral winter and the solar radiation intensity is weak right before and after the polar night period.

Figure 7(a) shows the time series of daily mean surface ozone concentration and UVB $(\lambda=290-325 \mathrm{~nm})$ measured by the Brewer Spectrograph at Zhongshan Station in 2008. The space between the two vertical lines in the Figure indicates the polar night period, during which there is no UVB. From the Figure it can be seen that the UVB in austral summer influenced the generation and decomposition of surface ozone. From March to the polar night period, as the solar radiation weakened, the surface ozone concentration continued to rise. In late July or early August, when sunrise began, the ozone concentration reached its maximum then started to decrease. This might result from the fact that the ozone precursors accumulated during the polar night period and led to an increase in surface ozone concentration. Then as the decreasing of ozone precursors, UVB destruction of ozone surpassed its photochemical production. Consequently, the ozone concentration began to decrease. Figure 7(b) presents the relationship between UVB and surface ozone. UVB was negatively correlated with surface ozone concentration, and the correlation coefficient was -0.69 . This implies that the photochemical destruction on surface ozone dominates in the Antarctic. This could occur because the Antarctic area is less polluted and short of ozone precursors, thus less ozone generated by photochemical reactions.
It can be seen from Figure 6 that during the Antarctic spring (August and September), the surface ozone concentration experienced several sudden decreases, which are referred to as ozone depletion events (ODE). These ODE might be related to chemical and dynamic processes. Take the ozone concentration falling below $50 \%$ of the annual mean value as the criterion for ODE, there occurred mainly two ODE at Zhongshan Station in 2008 (August 29-September 1, September 18-September 19). Both these ODE only lasted for a short period. Currently the bromine species consumption upon ozone in photochemical reaction has been widely acknowledged [15]. Zhongshan Station is located in the southeast coastal area of Prydz Bay, and the geography is appropriate for ODE. The relationships between ozone concentration and temperature, wind direction and wind speed during the occurrence of ODE at Zhongshan Station in 2008 were analyzed (Figure 8). This shows that during ODE the temperature suddenly dropped to below $-30^{\circ} \mathrm{C}$. This sudden drop in temperature facilitated the formation of new sea ice north of Zhongshan Station and the forming of frost flowers on the young ice. During this process the bromide in sea salt could be released into gas phase, which would increase the bromide concentration in the air. When the ODE occurred, the wind speed was lower, generally below $3 \mathrm{~m} \mathrm{~s}^{-1}$, which favored regional accumulation of bromide and reaction with ozone, thus bringing about ozone destruction. In addition, there was an obvious change in the wind direction, that is, the stable easterly winds changed to disorderly directions and the frequency of westerly winds increased. The Hybrid Single-Particle Lagrangian Integrated Trajectory Model (HYSPLIT) was used for further analysis of the ODE. Figure 9 shows the 2-day backward trajectories of August 28-31, 2008 at Zhongshan Station. Before the occurrence of the ODE (08:00 h, August 28), currents mainly came from the coastal areas of the Antarctic continent. When the airflow changed to coming from the sea area in the north (05:00 h, August 30), the ozone concentration began to drop. The ozone concentration rebounded until the airflow then came from coastal areas west of the station. The surface air temperature field from
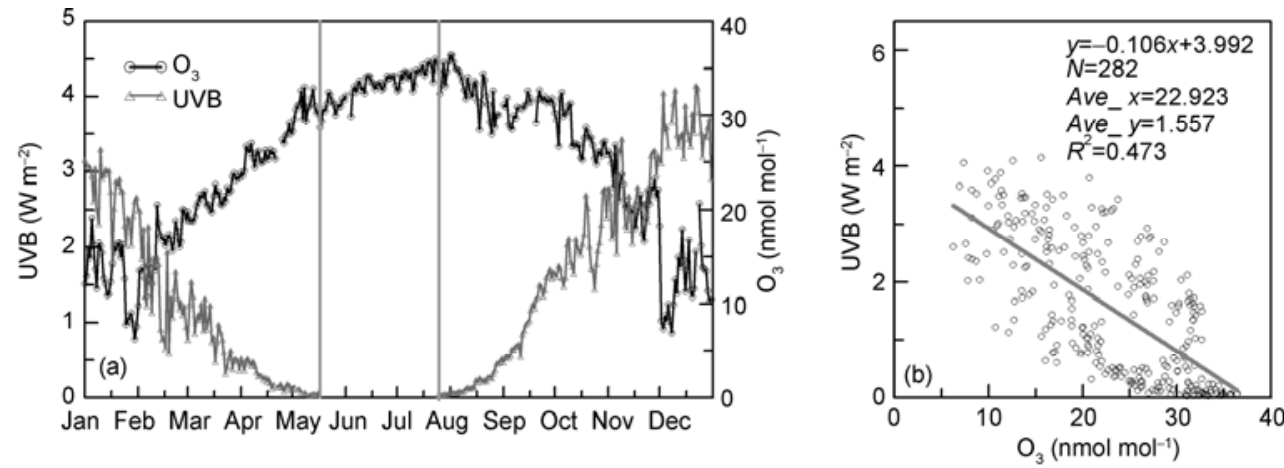

Figure 7 The time series of daily mean ultraviolet radiation (UVB) and surface ozone $\left(\mathrm{O}_{3}\right)$ concentration in 2008 (a) and their relationship (b). 
NECP reanalysis data (Figure 10) shows that before the ODE at Zhongshan Station (August 28), the temperature of the sea area north of the station was above $-30^{\circ} \mathrm{C}$ except Amery Ice Shelf in the south of Prydz Bay. When the ODE occurred (August 30), the temperature in Prydz Bay dropped obviously and the area with temperature below $-30^{\circ} \mathrm{C}$ expanded towards the south. When the ozone concentration began to recover (August 31), the temperature of the area rose above $-30^{\circ} \mathrm{C}$ again. This shows that the oc- currence of the ODE is related to temperature decreasing. Figure 11 shows the distribution of $\mathrm{BrO}$ vertical column in the southern hemisphere observed by the SCIAMACHY satellite. There were several regions with high $\mathrm{BrO}$ concentrations in the Antarctic sea ice areas, and these places were basically in line with those with temperature below $-30^{\circ} \mathrm{C}$. Prydz Bay was one of the $\mathrm{BrO}$ high-concentration areas, and with airflow the $\mathrm{BrO}$ of high concentration spread to the station, thus leading to the ODE. In addition, we also analyzed the relationship of surface ozone with carbon monoxide and
UVB during the occurrence of ODE, but found no obvious correlation.

\subsection{Annual mean surface ozone}

Helmiga et al. [7] pointed out that the annual mean concentration was influenced more by ozone depletion or increase events than the yearly median value. The ratio of the mean to the median can consequently be used to evaluate the impacts of ozone depletion or increase events on the annual mean ozone concentration. The annual mean surface ozone concentration at Zhongshan Station in 2008 was $25.0 \mathrm{nmol} \mathrm{mol}^{-1}$ while the median value was $26.3 \mathrm{nmol} \mathrm{mol}^{-1}$, which gave a ratio of 0.95 . In order to evaluate the representativeness of background monitoring of the surface ozone at Zhongshan Station, our data was compared with those observed at different stations in Antarctica (Figure 12). Among the selected stations only South Pole Station is situated inland while the other stations (Syowa, Neumayer, Arrival Heights) are all

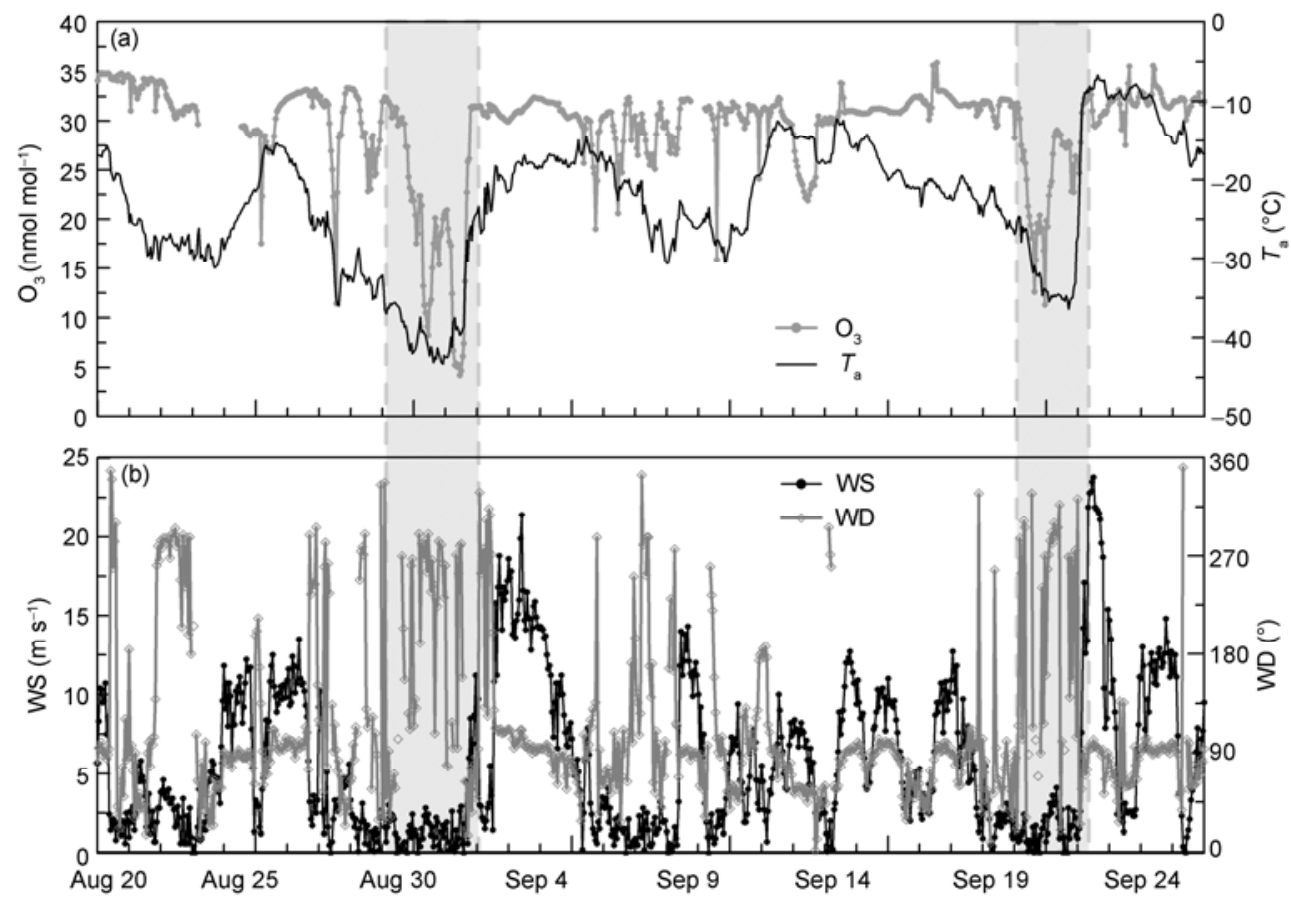

Figure 8 Time series of surface ozone $\left(\mathrm{O}_{3}\right)$ and the air temperature $\left(T_{\mathrm{a}}\right)(\mathrm{a})$, and the wind speed (WS) and wind direction (WD) (b) at Zhongshan Station from August 20 to September 24.

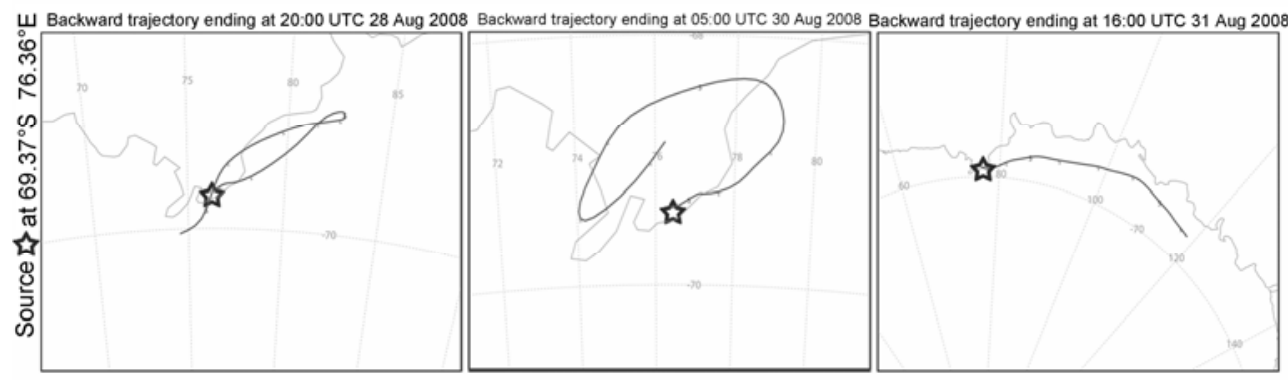

Figure 9 The 2-day backward trajectories for August 28, 30 and 31, 2008 at Zhongshan Station. 


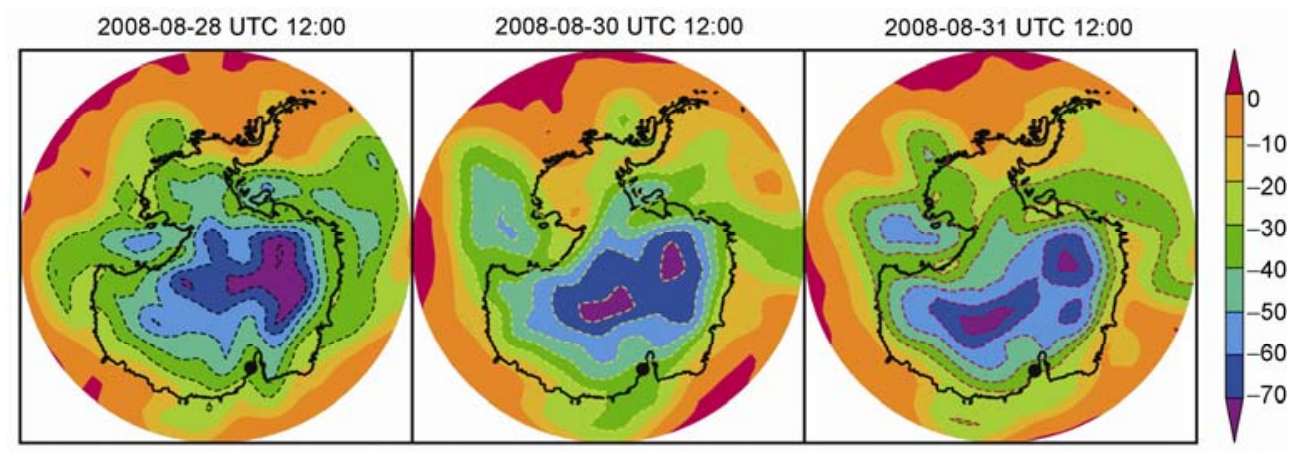

Figure 10 The NECP Reanalysis surface air temperature fields of August 28, 30 and 31, 2008, over Antarctica (http://www.esrl.noaa.gov/psd/cgi-bin/ db_search/DBSearch.pl?Dataset=NCEP+Reanalysis+Surface+Level\&Variable=Air+Temperature\&group=0\&submit=Search).
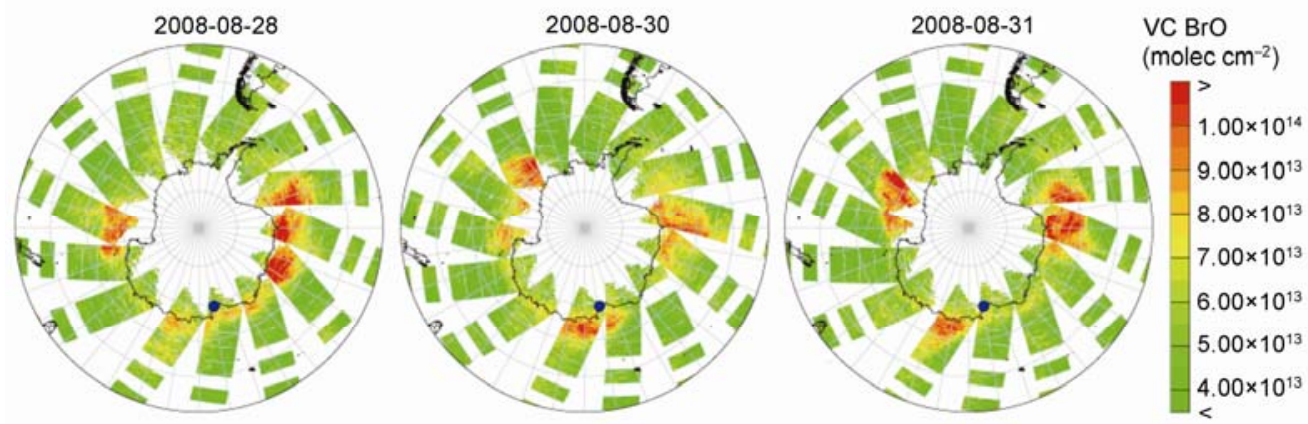

Figure 11 The distribution of BrO vertical column observed by SCIAMACHY satellite for August 28, 30 and 31, 2008.

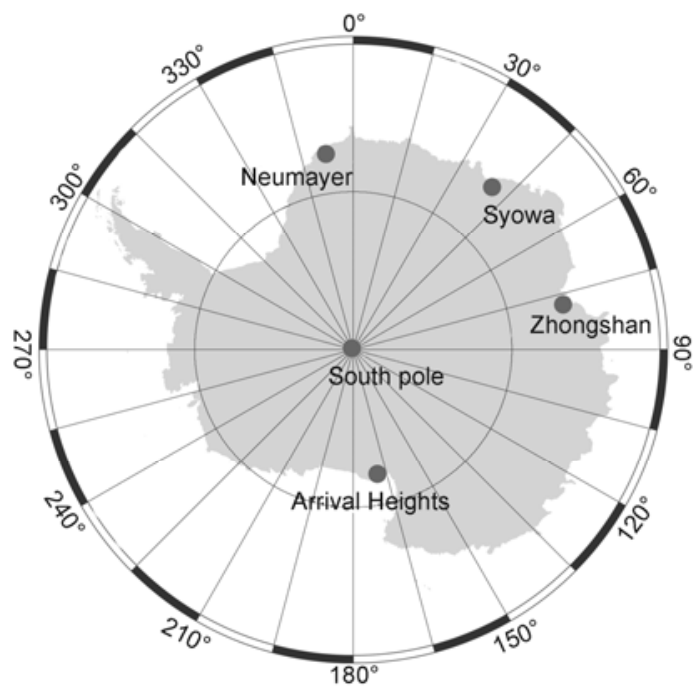

Figure 12 The distribution of surface ozone $\left(\mathrm{O}_{3}\right)$ monitoring stations over Antarctica.

located on the coastal areas. Table 1 shows the mean and median concentration of surface ozone at each station in 2008. The surface ozone concentration at South Pole Station is the highest one with a median value of $32.3 \mathrm{nmol} \mathrm{mol}^{-1}$, while the median values at coastal stations are around 26 nmol mol ${ }^{-1}$, about $6 \mathrm{nmol} \mathrm{mol}^{-1}$ lower than that at South Pole Station. The surface ozone concentration in the Antarctic is commonly about $5 \mathrm{nmol} \mathrm{mol}{ }^{-1}$ lower than those in the Arctic [7], which might be related to the limited pollution sources in the Southern Hemisphere. Table 1 also shows that besides South Pole Station, the mean concentration at Arrival Heights was slightly higher than those at the other stations, and the ratio between the mean and median was as high as 0.98 . This indicates that the impact of ozone depletion or increase events on the mean surface ozone concentration might be related to the altitude.

\section{Conclusions}

Based on the data of surface ozone at Zhongshan Station in 2008 and other relevant data, we analyzed the background characteristics of surface ozone, seasonal variation and the causes of ODE. The following conclusions are therefore arrived.

Analysis of the distribution of surface ozone concentration under different wind directions and wind speeds shows that short-time high concentrations only appeared in December when the wind was NW or SSE. There was no evidence shows that regional pollution sources influenced the surface ozone concentration at Zhongshan Station. Data that might contain this impact were removed and accounted for only $1 \%$ of the total. Consequently, the observation data can be used torepresent the background concentration of surface ozone at Zhongshan Station.

The surface ozone concentration at Zhongshan Station 
Table 1 The comparison of the surface ozone at different stations over Antarctica

\begin{tabular}{|c|c|c|c|c|c|}
\hline Stations & Location & Elevation (m) & Annual mean $\left(\mathrm{nmol} \mathrm{mol}{ }^{-1}\right)$ & Median (nmol mol $\left.{ }^{-1}\right)$ & Mean/Median \\
\hline South Pole & $90.00^{\circ} \mathrm{S}, 24.80^{\circ} \mathrm{W}$ & 2841 & 30.8 & 32.3 & 0.95 \\
\hline Syowa & $69.00^{\circ} \mathrm{S}, 39.58^{\circ} \mathrm{E}$ & 21 & 25.3 & 26.6 & 0.95 \\
\hline Arrival Heights & $77.83^{\circ} \mathrm{S}, 166.2^{\circ} \mathrm{E}$ & 250 & 26.3 & 26.9 & 0.98 \\
\hline Zhongshan & $69.37^{\circ} \mathrm{S}, 76.36^{\circ} \mathrm{E}$ & 18.5 & 25.0 & 26.3 & 0.95 \\
\hline
\end{tabular}

exhibited a seasonal variation with high values in winter and low values in summer. The surface ozone concentration was negatively correlated with UVB, which shows that the photochemical destruction is dominant.

Two obvious ODEs took place in the spring of 2008. These events were closely related to temperature decreasing, low wind speed and high BrO concentrations in areas north of station. Backward trajectory analysis suggested that the ODE at Zhongshan Station were mainly affected by BrO.

The annual mean surface ozone concentration at Zhongshan Station in 2008 was $25.0 \mathrm{nmol} \mathrm{mol}^{-1}$ and the median value was $26.3 \mathrm{nmol} \mathrm{mol}{ }^{-1}$. These values approximate those at other coastal stations in Antarctica and slightly lower than that at South Pole.

The background features of surface ozone at Zhongshan Station and the causes of ODE in the Antarctic spring could be used as a reference point for the analysis of other greenhouse gases.

We thank the Chinese Meteorological Administration (CMA) and Chinese Arctic and Antarctic Administration under the National Oceanic Administration (CAA) who provided support for building the atmosphere monitoring site at Zhongshan Station. All the members of the 24th and 25th Chinese Antarctic Expedition are acknowledged for their help collecting the data. In addition, we are grateful to the Institute of Environmental Physics of the University of Bremen (Germany) who provided the BrO satellite-observed data. This work was supported by the National Natural Science Foundation of China (41076132) and the MOST Program of China (2006BAB18B05).

1 Wang M X. Atmospheric Chemistry (in Chinese). 2nd ed. Beijing: China Meteorological Press, 1999. 340

2 Wang Z Y, Li H Y, Zhou S K. Review of chemical depletion of the stratospheric ozone (in Chinese). Chinese Sci Bull, 2001, 46: 619-625

3 IPCC. Climate Change 2007: The Physical Science Basis. In: Solomon S, Qin D H, Manning M, et al, eds. Contribution of Working Group I to the Fourth Assessment Report of the Intergovernmental Panel on Climate Change. Cambridge: University Press, 2007. 149-152

4 Jia L, Ge M F, Xu Y F, et al. Advances in atmospheric ozone chemistry (in Chinese). Prog Chem, 2006, 18: 1565-1574

5 Wang W C. Coupled effects of atmospheric $\mathrm{N}_{2} \mathrm{O}$ and $\mathrm{O}_{3}$ on the earth's climate. Nature, 1979, 268: 589-590

6 Xu X B, Ding G A, Li X S, et al. Variability and related factors of the surface ozone at Longfeng Shan in Northeast China (in Chinese). Acta Meteorol Sin, 1998, 56: 560-572

7 Helmiga D, Oltmans S J, Carlson D, et al. A review of surface ozone in the polar regions. Atmos Environ, 2007, 41: 5138-5161

8 Vingarzan R. A review of surface ozone background levels and trends. Atmos Environ, 2004, 38: 3413-3442

9 Wexler H, Moreland W B, Weyant W S. A preliminary report on ozone observations at Little America, Antarctica. Mon Wether Rev, 1960, 88: 43-54

10 Oltmans S J, Komhyr W D. Surface ozone in Antarctica. J Geophys Res, 1976, 81: 5359-5364

11 Oltmans S J. Surface ozone measurements in clean air. J Geophys Res, 1981, 86: 1174-1180

12 Kreher K, Keys J G, Johnston P V, et al. Ground based measurements of $\mathrm{ClO}$ and $\mathrm{HCl}$ in austral spring 1993 at Arrival Heights, Antarctica. Geophys Res Lett, 1996, 23: 1545-1548

13 Barrie L A, Bottenheim J W, Schnell R C, et al. Ozone destruction and photochemical reactions at polar sunrise in the lower Arctic atmosphere. Nature, 1988, 334: 138-141

14 Fan S M, Daniel J J. Surface ozone depletion in Arctic spring sustained by bromine reactions on aerosols. Nature, 1992, 359: 522-524

15 Simpson W R, Glasow R, Riedel K, et al. Halogens and their role in polar boundary-layer ozone depletion. Atmos Chem Phys Discuss, 2007, 7: 4285-4403

16 Wagner T, Leue C, Wenig M, et al. Spatial and temporal distribution of enhanced boundary layer $\mathrm{BrO}$ concentrations measured by the GOME instrument aboard ERS-2. J Geophys Res, 2001, 106: 24225-24235

17 Zhou X J, Zheng X D, Lu L H, et al. Ground-based measurments of column amounts of ozone and UVB over Zhongshan Station, Antarctica, in the 1993 "ozone hole" (in Chinese). Antarct Res, 1994, 6: 14-22

18 Zhen X D, Zhou X J, Lu L H, et al. The ozone hole observing study at Antarctic Zhongshan Station in 1993 (in Chinese). Chinese Sci Bull, 1995, 40: 533-535

19 Zheng G X D, Lu L H, Zhou X J. A study on the 6-year observation of the spring ozone depletion at Zhongshan Station, Antarctica (in Chinese). Chin J Polar Res, 1999, 11: 265-274

20 Guo S, Zhou X J, Zheng X D, et al. The measurements and analyses of ozone profile during the "ozone hole" period over Zhongshan Station, Antarctica (in Chinese). Chin J Polar Res, 1997, 9: 78-82

21 Lu L H, Bian L G, Chen Y J, et al. Observations during voyages to the Arctic and Antarctic regions: Chinese Sci Bull, 2001, 46: 1995-2000

22 Xie Z Q, Sun L G, Wang X M, et al. Mercury depletion in the Arctic atmosphere regarding to the sea ice change (in Chinese). Chin J Polar Res, 2004, 16: 221-228

23 Afe $\mathrm{O}$ T. Retrieval and Observations of Atmospheric BrO from SCIAMACHY nadir Measurements. Dissertation for the Doctoral Degree. Bremen: University of Bremen, 2005

24 Sinnhuber B-M, Rozanov A, Sheode N, et al. Global observations of stratospheric bromine monoxide from SCIAMACHY, Geophys Res Lett, 2005, 32: L20810

25 Zhou L X, Tang J, Wen Y P, et al. Impact of local surface wind on the atmospheric carbon dioxide background concentration at Mt. Waliguan (in Chinese). Acta Sci Circums, 2002, 22: 135-139

26 Zhou L X, Wen Y P, Li J L, et al. Impact of local surface winds on atmospheric methane background concentration at Mt. Waliguan (in Chinese). J Appl Meteoro Sci, 2004, 15: 257-265

27 Schnell R C, Liu S C, Oltmans S J, et al. Decrease of summer tropospheric ozone concentrations in Antarctica. Nature, 1991, 351: 726- 729

Open Access This article is distributed under the terms of the Creative Commons Attribution License which permits any use, distribution, and reproduction in any medium, provided the original author(s) and source are credited. 